\title{
INFLUENCE OF HIGH TEMPERATURES ON TECHNICAL STATE OF STREETS AND ROADS STRUCTURES WITH ASPHALT SURFACING
}

Mihai DICU, professor dr. eng. Faculty of Railways, Roads and Bridges, Technical University of Civil Engineering of Bucharest, Romania, e-mail: mdicu5@yahoo.com

Isam MIRZA, eng., phd. student at Technical University of Civil Engineering of Bucharest (Faculty of Railways, Roads and Bridges), e-mail: isammirza@ hotmayl.com

Flavius - Florin PAVĂL, phd. student at Technical University of Civil Engineering of Bucharest (Faculty of Railways, Roads and Bridges), Head of Traffic Safety Office, National Company For Roads Infrastructure Administration, e-mail: paval.flavius@ yahoo.com

\section{Rezumat}

În cadrul acestui articol va fi prezentată influența temperaturilor ridicate asupra îmbrăcăminților rutiere asfaltice stradale, din punct de vedere al influenței acestor temperaturi asupra deformațiilor permanente și implicit asupra stării tehnice la străzi, comparabil cu efectele induse asupra drumurilor extraurbane.

Factorii de mediu reprezintă unul dintre principalii factorii de agresare a structurilor rutiere aflate in exploatare și sunt foarte importanți din punct de vedere al influenței pe care o pot avea asupra stării tehnice a infrastructurilor de transport rutier.

Vor fi prezentate diferențele dintre structurile rutiere urbane (străzi) și cele extraurbane (drumuri) atât din punct de vedere constructiv, al solicitărilor din trafic, precum și a condițiilor de mediu la care sunt supuse.

Structurile rutiere extraurbane și cele urbane sunt solicitate diferit din punct de vedere al condițiilor de mediu datorită amplasării ambientale diferite a acestora, respectiv în cazul străzilor acestea se găsesc în interiorul localităților iar mediul antropic construit influențează în mod semnificativ infrastructura rutieră, spre deosebire de cazul drumurilor unde acestea sunt situate numay în afara localităților, curenții de aer reducând efectul de acumulare a temperaturii la suprafaţa îmbrăcăminții asfaltice.

Pentru demonstrarea influenței temperaturilor ridicate asupra îmbrăcăminților rutiere au fost efectuate încercări de laborator asupra mixturilor asfaltice cu scopul de a demonstra apariția de reduceri a caracteristicilor fizico-mecanice, $\mathrm{cu}$ implicatii defavorabile asupra performanțelor la solicitări asimilate traficului rutier.

Cuvinte cheie: temperaturi ridicate, îmbrăcăminți rutiere, străzi, stare tehnică 


\title{
ROMANIAN JOURNAL \\ OF TRANSPORT INFRASTRUCTURE
}

Mihai DICU, Isam MIRZA, Flavius - Florin PAVĂL

Influence of high temperatures on technical state of streets and roads structures with asphalt surfacing

\begin{abstract}
In this paper will be presented the influence of high temperatures on asphalt street pavement in terms of the influence of temperature on permanent deformations and thus the technical condition of the streets, comparable to the effects induced on extra-urban roads.

Environmental factors are one of the mayn factors being assaulted in operation and road structures are very important in terms of the influence they can have on the state road transport technical infrastructure.

Will be presented differences between urban road structures (streets) and extra-urban (road) both in terms of construction, the demands of traffic and environmental conditions to which they are subject.

Road structures extra-urban and urban areas are required differently in terms of the environmental conditions of the location ambient different thereof, that is, when the streets they are inside localities and the built environment significantly affect road infrastructure, unlike in the case of roads where they are located just outside the settlements, reducing the effect of air currents accumulation pavement surface temperature.

To demonstrate the influence of high temperatures on the pavement were conducted laboratory tests on asphalt mixtures in order to demonstrate the occurrence of reduction of physical characteristics, with adverse implications on the performance of applications similar to traffic.
\end{abstract}

Keywords: high temperature, road surfaces, streets, technical state

\section{URBAN ROAD INFRASTRUCTURE (STREETS) AND THOSE EXTRA URBAN (ROADS)}

Inside the cities, road infrastructures are called streets and the extra-urban linking towns are called roads precisely in order to make the distinction of behavior under the action of the factors like road traffic, as well as variations in environmental factors, and the present paper detailing the effects of high summer temperatures.

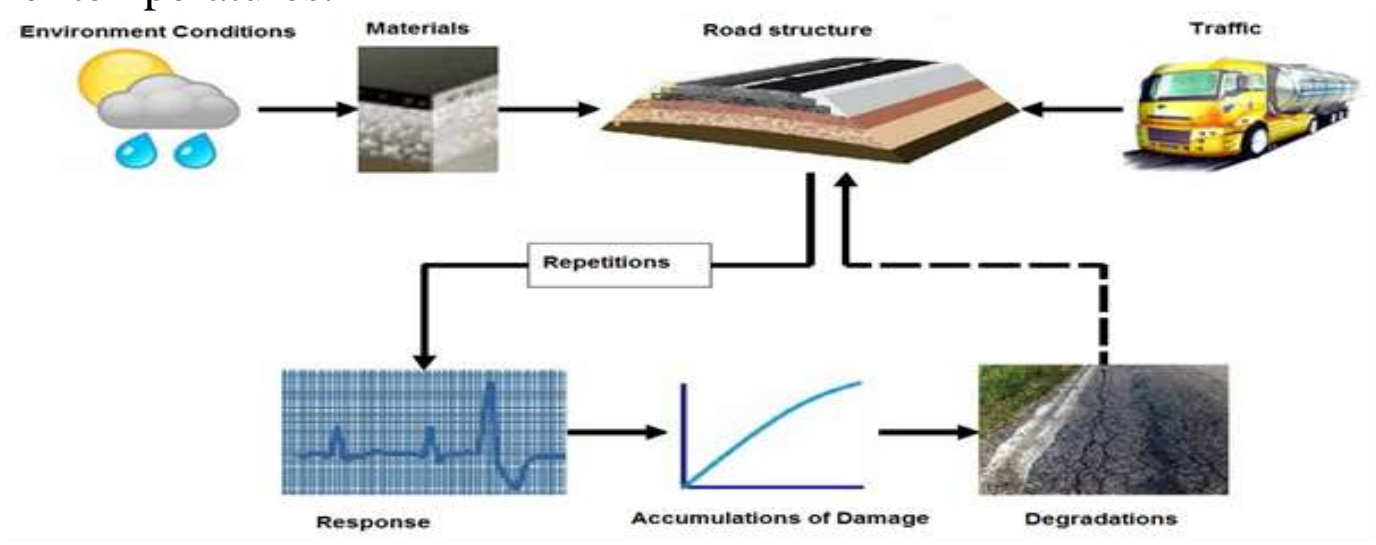


Figure 1. Road structures and their behavior

At first sight, the streets and roads extra urban are similar functional terms, but excluding the role for which they are constructed, namely to ensure the connection between human settlements and facilitate vehicle traffic, they differ greatly both in terms of construction as and the stresses to which they are subject.

In the general acceptation, the streets are recognized as urban road communication ways and represent basically the transport infrastructure of settlements. In fact, the street is an urban road, which supports besides road traffic and pedestrian traffic. ${ }^{[1]}$

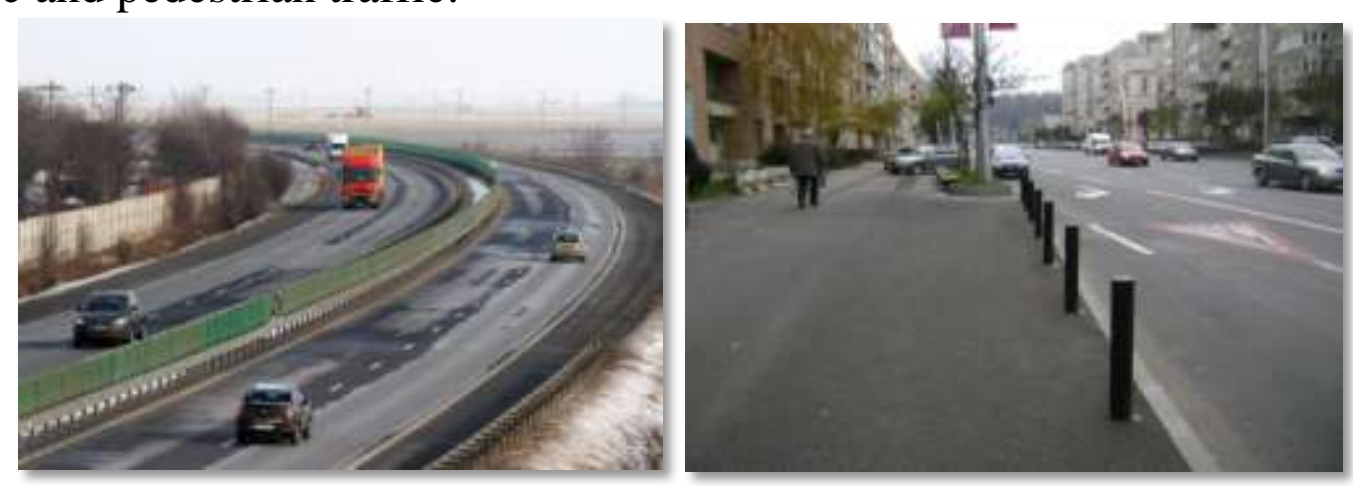

Figure 2. Difference between streets and roads ${ }^{[4]}$

Urban road transport infrastructures, namely STREETS, constructive differ widely from extra urban road transport infrastructure - roads, and these differences are shown in the following table:

Table 1. Constructive differences between roads and streets

\begin{tabular}{|l|l|}
\hline \multicolumn{2}{|c|}{ CONSTRUCTIVE DIFFERENCES } \\
\hline \multicolumn{1}{|c|}{ ROADS } & \multicolumn{1}{c|}{ STREETS } \\
\hline carriage way & carriage way; \\
\hline hard shoulders & sidewalks; \\
\hline road platform & road platform, bicycle lanes and trams (tram lines); \\
\hline slopes & green areas for connection to building boundaries; \\
\hline ditches & framing borders \\
\hline bench seat & $\begin{array}{l}\text { bands stationary and parking spaces adjacent to the } \\
\text { roadway or sidewalks; }\end{array}$ \\
\hline road reservation & $\begin{array}{l}\text { street reservation witch include green areas reserved for } \\
\text { underground installations, lighting or telephone poles, } \\
\text { parapets, road signs, plantations, urban networks; }\end{array}$ \\
\hline
\end{tabular}


ROMANIAN JOURNAL

OF TRANSPORT INFRASTRUCTURE

Mihai DICU, Isam MIRZA, Flavius - Florin PAVĂL

Influence of high temperatures on technical state of streets and roads structures with asphalt surfacing

\begin{tabular}{|l|l|}
\hline safety zones & green areas framed with borders for construction joints. \\
\hline
\end{tabular}

The users of road transport infrastructure are mostly the same, with small differences, both for roads and streets, but differs their report and thus the effects they produce in the case of extra urban road infrastructure and in the case of urban road infrastructure.

Table 2. The users of road infrastructure

\begin{tabular}{|c|c|c|c|}
\hline \multicolumn{4}{|c|}{ THE USERS } \\
\hline ROADS & THE USABILITY & STREETS & $\begin{array}{c}\text { THE } \\
\text { USABILITY }\end{array}$ \\
\hline Large vehicles & $\begin{array}{l}\text { permanent/ } \\
\text { very big }\end{array}$ & Large vehicles & $\begin{array}{l}\text { rarely / } \\
\text { medium }\end{array}$ \\
\hline Passenger Cars & big & Passenger Cars & $\begin{array}{l}\text { permanent/ } \\
\text { very big }\end{array}$ \\
\hline $\begin{array}{c}\text { Cyclists / } \\
\text { Pedestrian traffic }\end{array}$ & $\begin{array}{c}\text { rarely/ } \\
\text { almost nonexistent }\end{array}$ & $\begin{array}{c}\text { Cyclists / } \\
\text { Pedestrian traffic }\end{array}$ & $\begin{array}{c}\text { permanent/ } \\
\text { big }\end{array}$ \\
\hline & & Trams & $\begin{array}{l}\text { permanent/ } \\
\text { very big }\end{array}$ \\
\hline & & Utility networks & $\begin{array}{l}\text { permanent/ } \\
\text { very big }\end{array}$ \\
\hline
\end{tabular}

\section{THE STRESS APPLIED ON STREETS IN COMPARISON WITH THE ONE OF THE ROAD}

Urban road structures differ greatly from those extraurban in terms of the stresses to which they are subject.
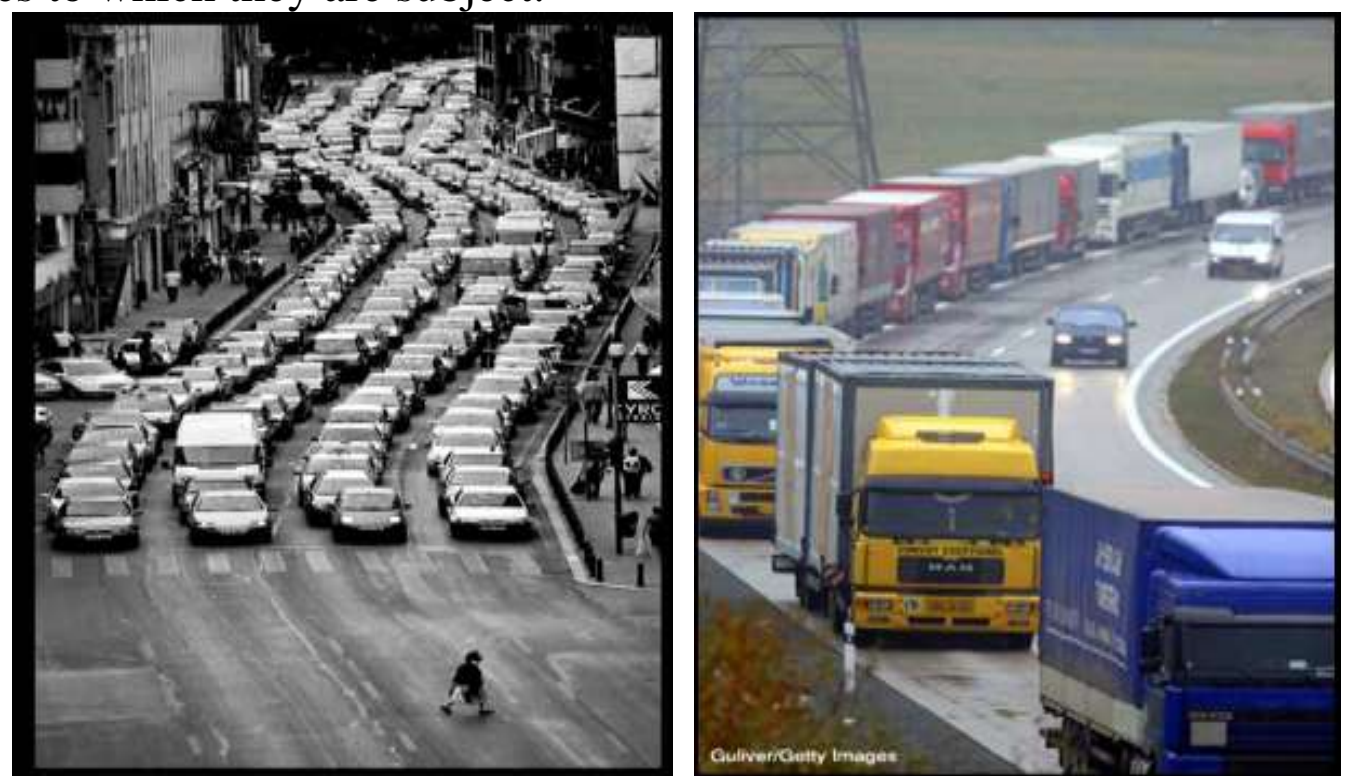
Figure 3. Urban road traffic (left) and extraurban traffic (right) ${ }^{[4]}$

If the road traffic is mostly composed of heavy vehicles, which are in relatively large numbers, traffic on the streets consists for the most from passenger cars, but in an extremely large number. On the streets meet and heavy vehicles or transport vehicles such as buses and trolleybuses, which are in large numbers on some streets that are sized accordingly.
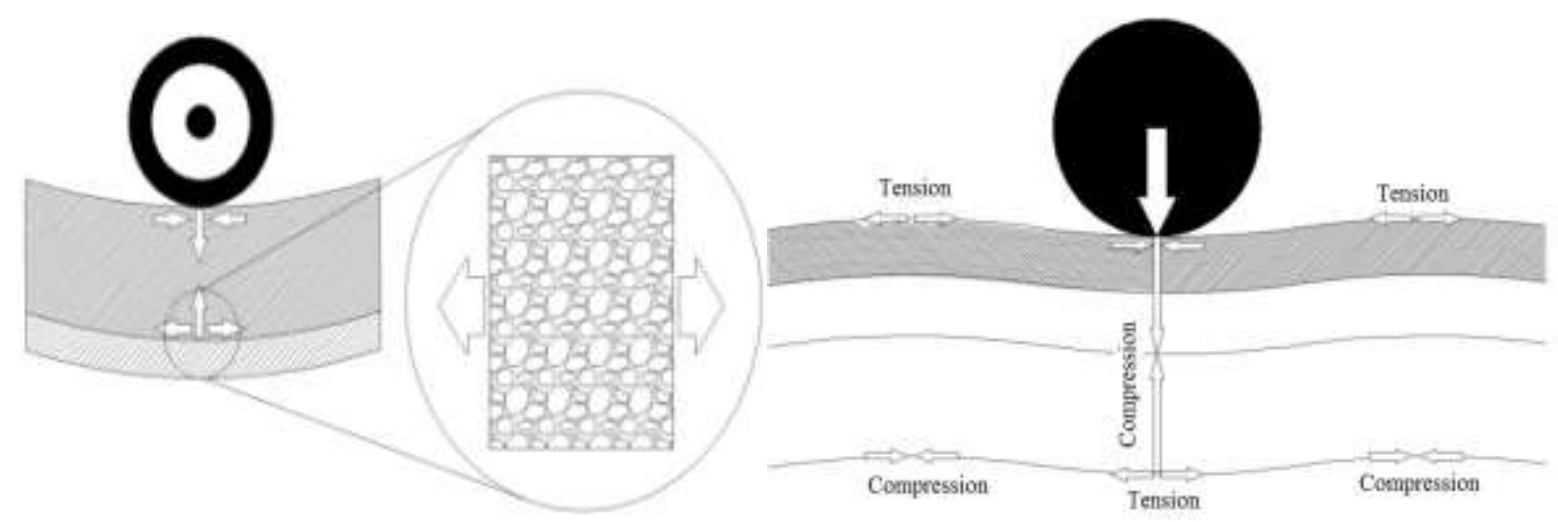

Figure 4. The efforts from a road structure ${ }^{[4]}$

The stress applied on urban road structures is very different from the extraurban ones because within the localities are extremely large number of accelerations - decelerations at the frequent intersections of an urban network, as well as pedestrian crossings leading to high shear stresses, that lead to the degradation maynly to hardcovering.
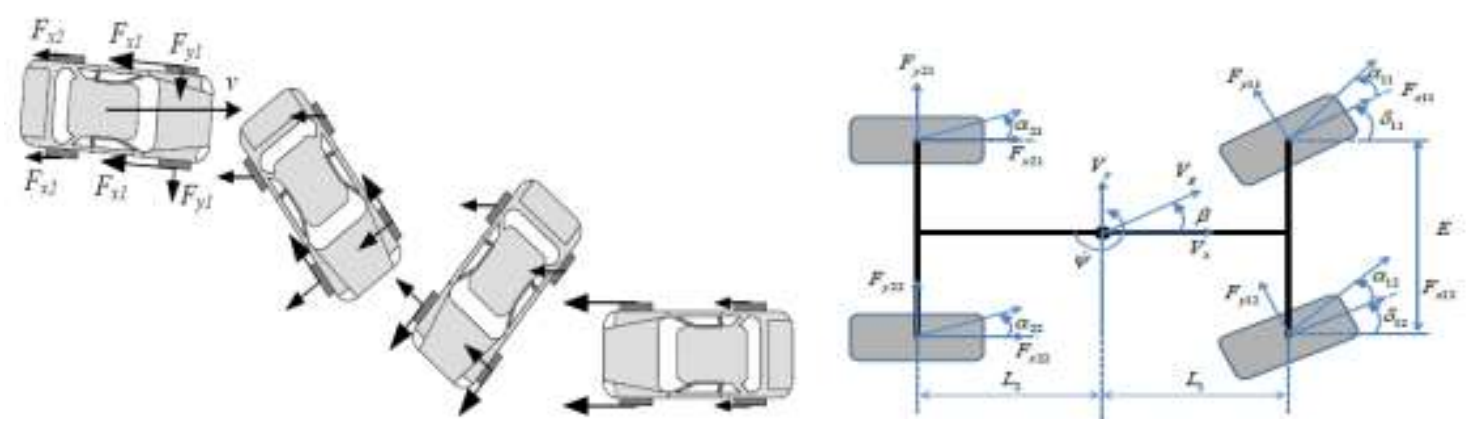

Figure 5. Tangential efforts to the surface of carriageway

The road structure degradations occur in the streets especially after the interventions to underground utility networks, under roadway of streets and 


\section{ROMANIAN JOURNAL}

\section{OF TRANSPORT INFRASTRUCTURE}

Mihai DICU, Isam MIRZA, Flavius - Florin PAVĂL

Influence of high temperatures on technical state of streets and roads structures with asphalt surfacing

restoration can not comply with the same conditions of quality at their initial construction.

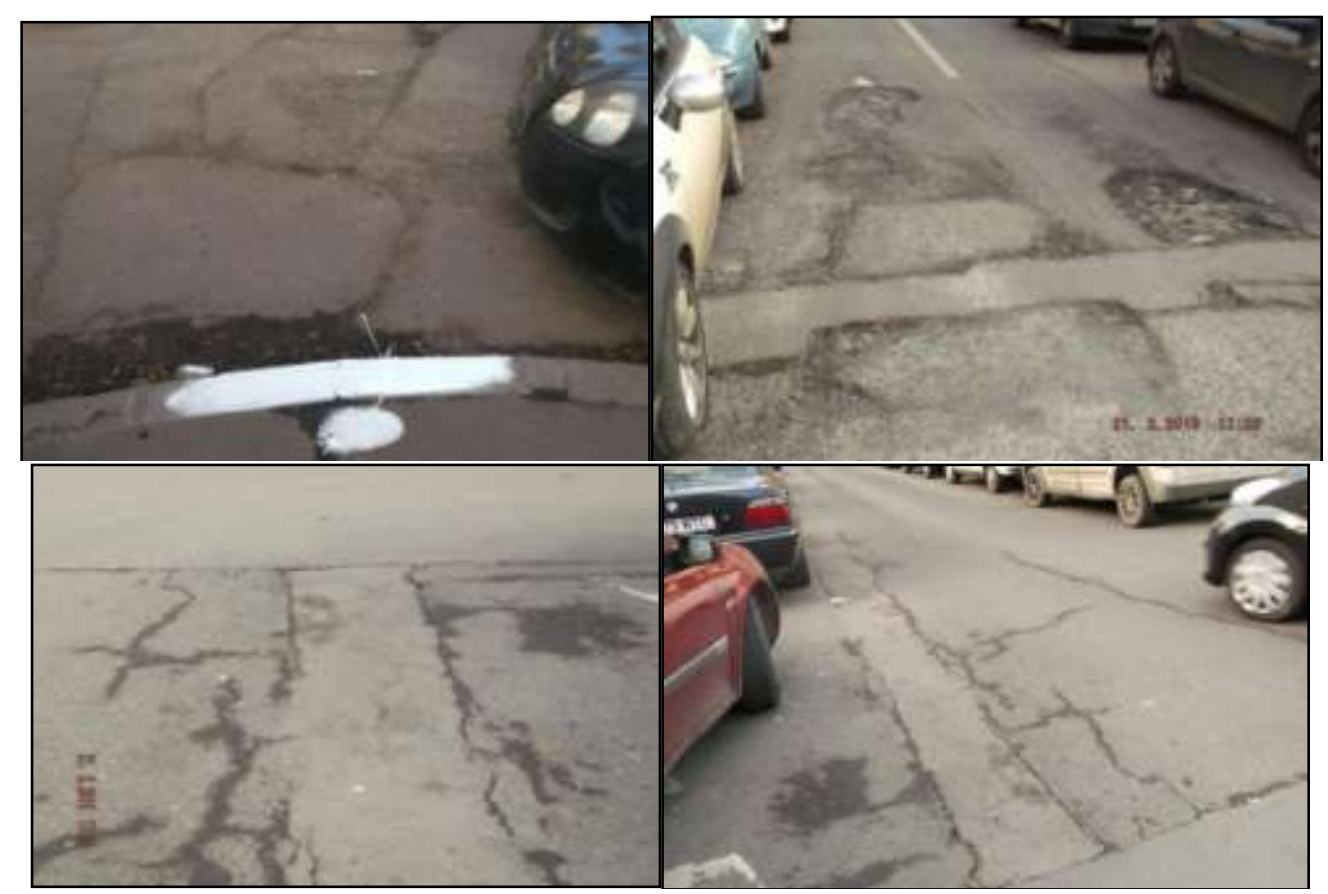

Figure 6. Degradation of the urban road structures

In addition to road traffic, we are experiencing variations in environmental factors. Road structures are constructions that support permanent stresses due to temperature variations, water, wind, etc. and they also suffer their destructive actions.
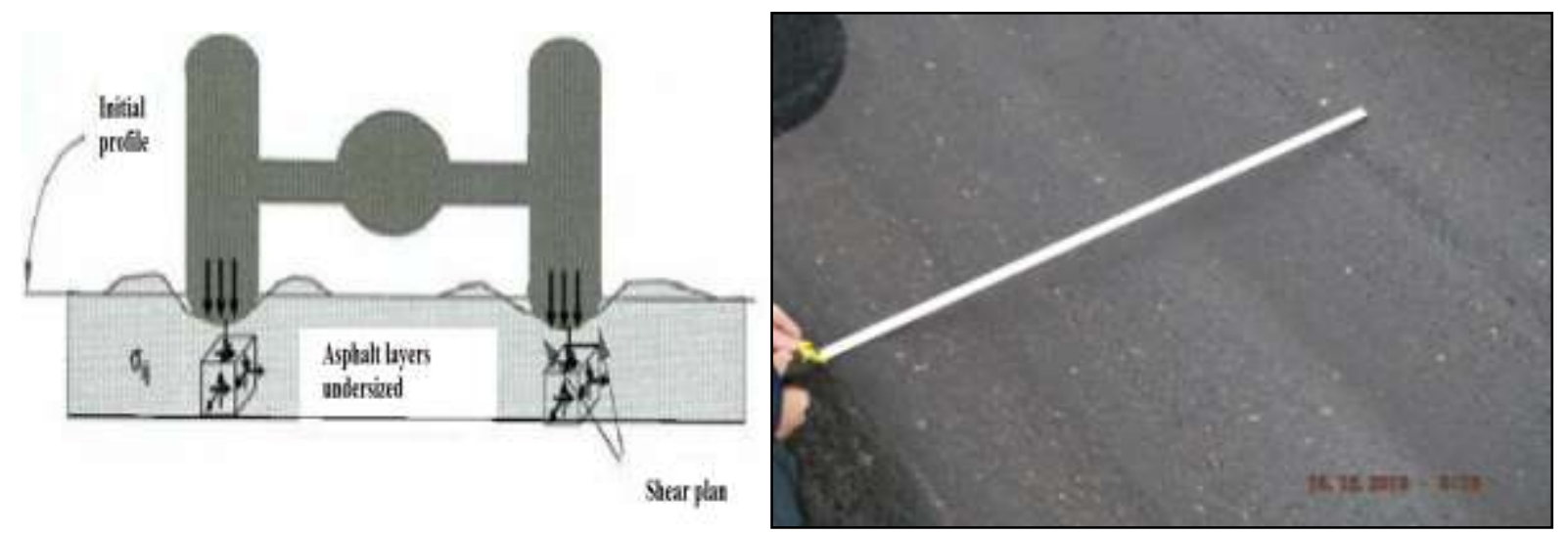

Figure 7. The behavior of road structure in the case of degradations 
The appearance of these degradations involves the application of intervention programs that are the result of complex analysis, as suggested in the following figure, which represents a more detailed analysis and behavior of the mix asphalt pavement at high temperatures.

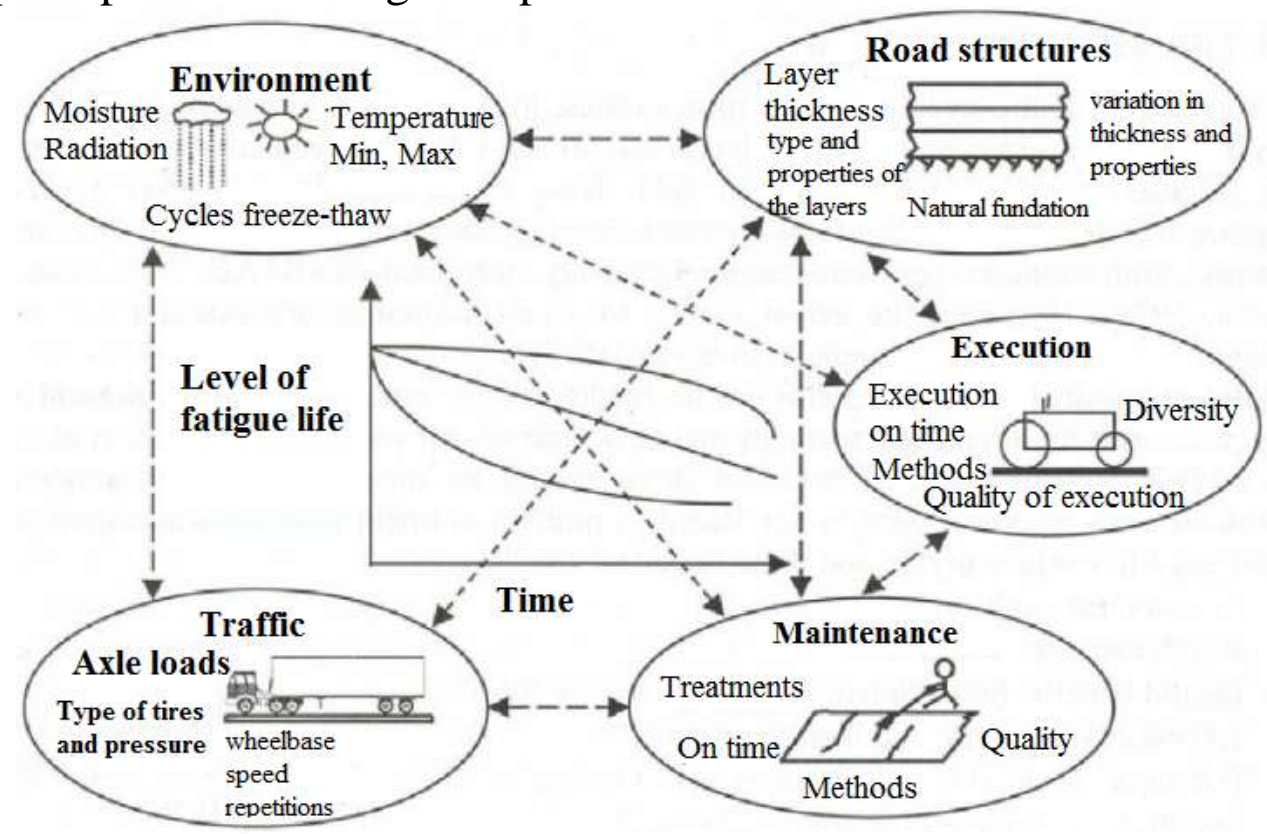

Figure 8. The analysis conducted within the intervention program

\section{URBAN AND EXTRAURBAN TEMPERATURES}

In addition the cold sezon, the summer leads to structural damage due to the very high temperatures can reach $40-50^{\circ}$ Celsius in the air and while on the road are much higher.

Here from streets, roads and we find major differences as within cities temperatures are recorded at the level of the roadway are much higher than on the roads because there is a large number of machines (heat from their engines especially when using the air conditioning), lack of vegetation and preventing movement currents (due to tall buildings adjacent to the road) influence significantly to rising temperatures.

During the warm period of the year respectively the months from May to September, high temperatures drastically influence the technical condition of the road network with stress applied because they contribute with the traffic to the appearance of permanent deformations and finally to degradations.

It should be considered that pavement temperatures are much higher than those of air as shown in the following figure: 


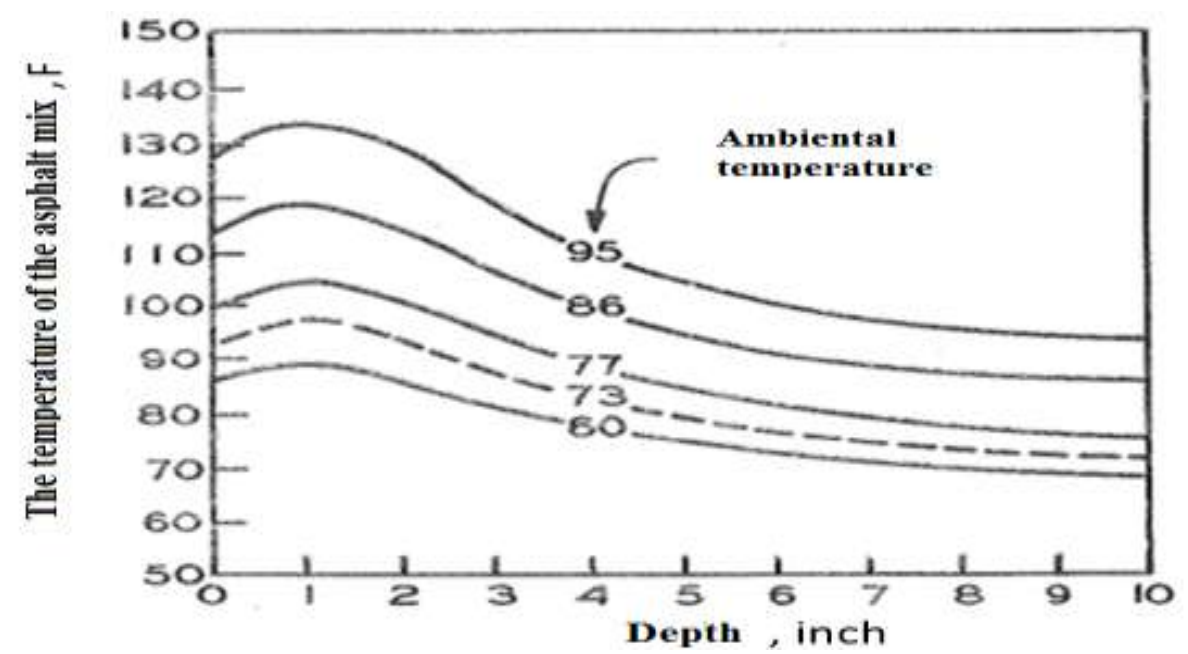

Figure 9. Interdependence between air temperature - the temperature mix asphalt - road surfacing depth ${ }^{[2]}$

Thus, they were taken into consideration maximum temperatures during the warmer months in three locations (one location is in south Bucharest, one in the north in Cluj-Napoca and one outside of the village, Poiana Stampei) in the period 2013-2015, in order to highlight pavement temperatures stored in the structure:

Table 3. Maximum temperatures in the air during 2013-2016

\begin{tabular}{|r|c|c|c|}
\hline \multirow{2}{*}{ Data } & \multicolumn{3}{|c|}{ Temperaturi / Statie ( $\left.{ }^{\mathbf{0}} \mathbf{C}\right)$} \\
\cline { 2 - 4 } & Bucuresti (Filaret) & Cluj Napoca & Poiana Stampei \\
\hline september-2015 & 36,2 & 33,5 & 29,2 \\
\hline august-2015 & 37,7 & 34,4 & 29,0 \\
\hline july-2015 & 37,8 & 33,1 & 29,4 \\
\hline june-2015 & 33,7 & 31,3 & 26,7 \\
\hline may-2015 & 29,0 & 26,6 & 24,0 \\
\hline september-2014 & 30,1 & 27,9 & 22,8 \\
\hline august-2014 & 36,5 & 34,8 & 29,6 \\
\hline july-2014 & 33,6 & 30,4 & 25,1 \\
\hline june-2014 & 31,2 & 30,7 & 25,7 \\
\hline may-2014 & 29,5 & 28,0 & 21,5 \\
\hline september-2013 & 33,4 & 25,7 & 21,7 \\
\hline august-2013 & 37,2 & 35,3 & 30,2 \\
\hline july-2013 & 36,3 & 35,2 & 27,1 \\
\hline june-2013 & 35,0 & 31,7 & 25,7 \\
\hline may-2013 & 32,2 & 28,1 & 21,7 \\
\hline
\end{tabular}




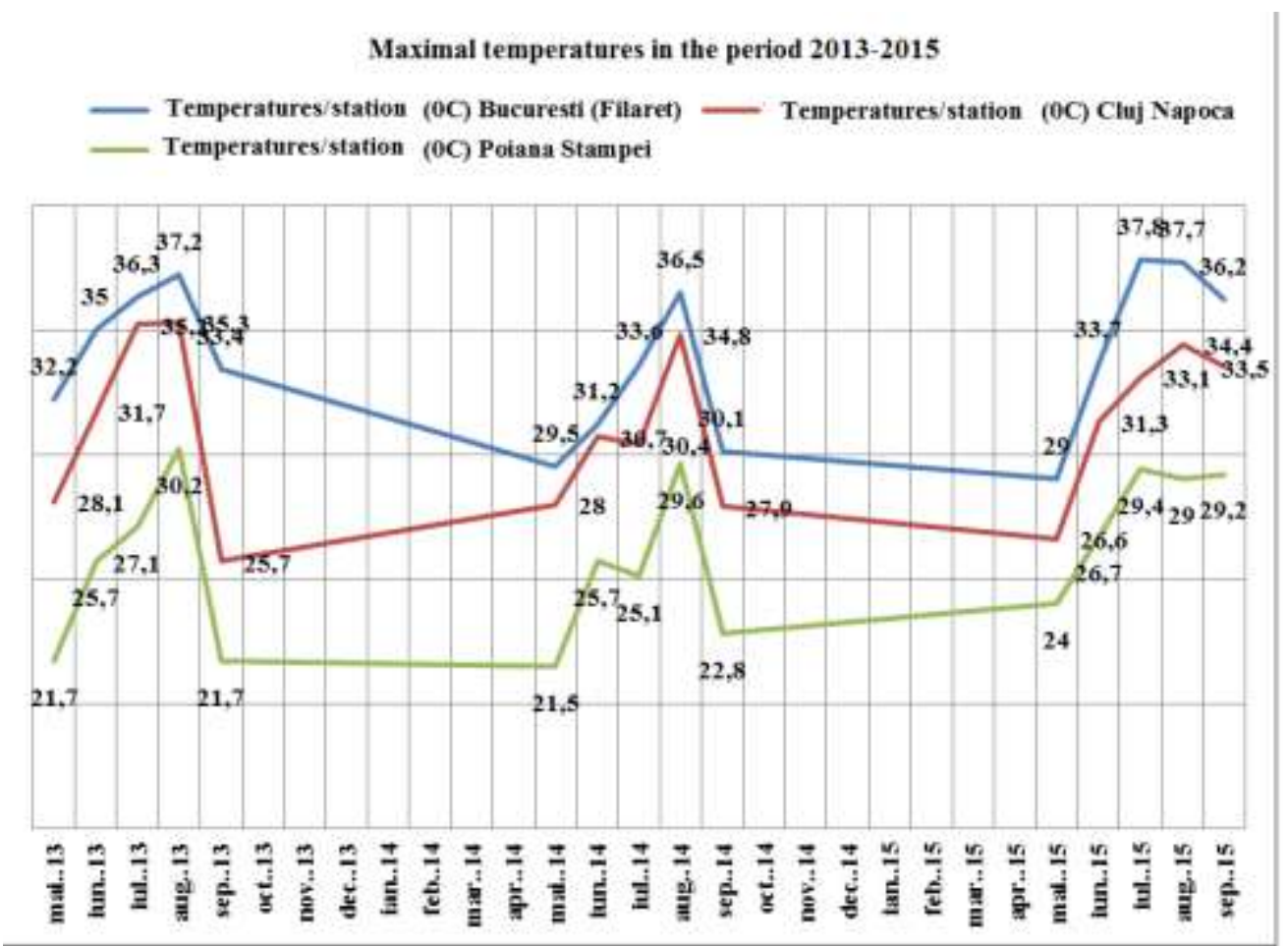

Figure 10. Maximal temperature between 2013 - 2015

Are observed differences about $+3^{0} \mathrm{C}$, between the localities of the south and the north, but also a significant temperature increase of $+3---+6{ }^{0} \mathrm{C}$, between the village and outside the village. Is also possible to be observed significant temperature increases in the hot summer months.

Therefore it is very important to supplement field observations with laboratory research, in terms of performance of the asphalt at increased temperature, according to a procedure which is outlined below.

\section{LABORATORY TESTS}

The behavior of asphalt mixes can be determined by both classical and dynamic tests. This study evaluated the performance of asphalt mixes on the influence of high temperatures by the dynamic creep test carried out in the Road Laboratory of the Faculty of Roadways and Bridges of the Technical University of Civil Engineering in Bucharest.

The materials in the composition of these asphalt mixes are as follows: the 8-16 type crate comes from the Red Taul in Baia Mare, the limestone fillet used is a holcim filler from the Alsed factory, the bitumen used is a D50 bitumen road 


\section{ROMANIAN JOURNAL}

\section{OF TRANSPORT INFRASTRUCTURE}

Mihai DICU, Isam MIRZA, Flavius - Florin PAVĂL

Influence of high temperatures on technical state of streets and roads structures with asphalt surfacing

type / 70 Italia, an additive for increasing the adhesion of INTERLENE IN 400$\mathrm{S}$, and Viatop 66 fiber from Ichi Impex SRL.

The recipes were designed with both Marshall (for all static tests) and roundabout (for all dynamic tests).
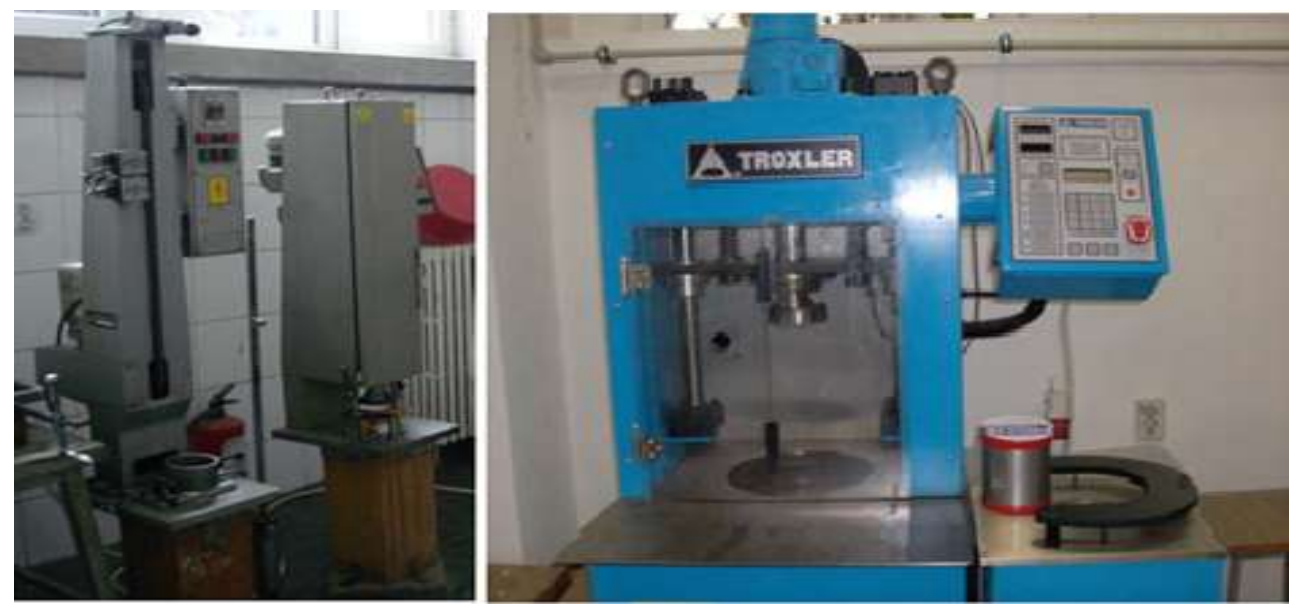

Figure 11. Marshall Equipment and Girocompactor

The recipe of the aggregate mixture is shown in the figure of the curve of the agglomerate curve in the granulometric range (figure 12), and the granulometric curve for the asphalt mix MAS 16 in Table 4.

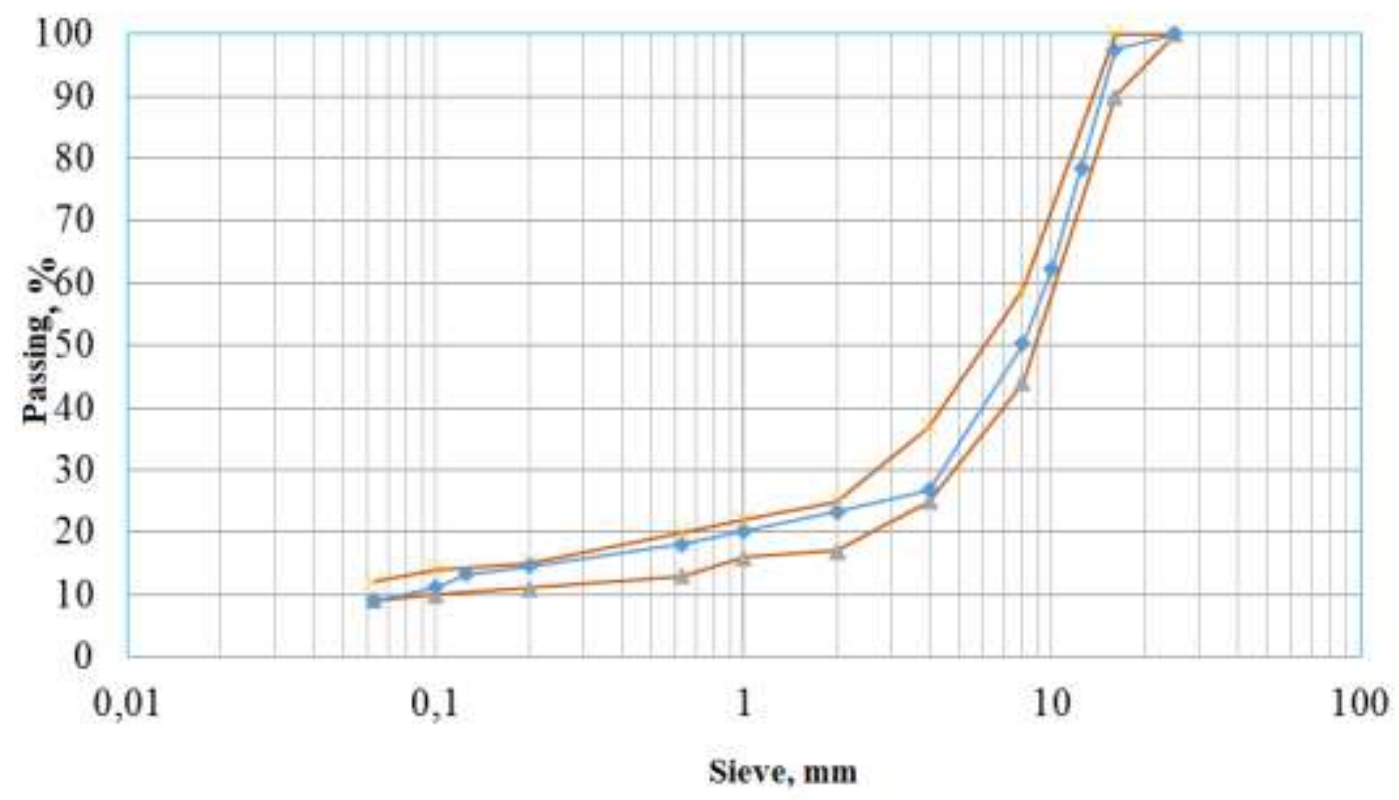

$\multimap$ Inferior limits $\quad$ Superior limits $\quad \rightarrow$ Granulometric curve MAS 16 
Figure 12. Incorporation of the aggregate mixture curve in the particle size range

Table 4. Mixed recipe MAS 16

\begin{tabular}{|c|c|c|c|c|c|}
\hline \multirow[t]{2}{*}{ Material } & \multicolumn{2}{|c|}{ Recipe } & \multirow{2}{*}{$\begin{array}{c}\text { Technical } \\
\text { condition } \\
\text { from AND } \\
605 / 2013\end{array}$} & \multirow{2}{*}{$\begin{array}{c}\text { Technical } \\
\text { condition } \\
\text { from AND } \\
605 / 2014\end{array}$} & \multirow{2}{*}{$\begin{array}{c}\text { Category } \\
\text { conforme } \\
\text { SR EN 13108-5 }\end{array}$} \\
\hline & $\begin{array}{l}(\%) \text { in } \\
\text { mixture }\end{array}$ & $\begin{array}{c}(\%) \\
\text { from } \\
\text { aggregate }\end{array}$ & & & \\
\hline Chippings 8-16 & 45.96 & 49.00 & \multirow{2}{*}{$\begin{array}{c}63 \ldots 75 \% \\
(\mathrm{~A})\end{array}$} & \multirow{2}{*}{$\begin{array}{c}63 \ldots 75 \% \\
\text { (A) }\end{array}$} & - \\
\hline Chippings 4-8 & 22.51 & 24.00 & & & - \\
\hline $\begin{array}{c}\text { Sand crushing } \\
0-4\end{array}$ & 15.01 & 16.00 & $\begin{array}{c}\text { Difference to } \\
100 \%(\mathrm{~A})\end{array}$ & $\begin{array}{l}\text { Difference } \\
\text { to } 100 \%(\mathrm{~A})\end{array}$ & - \\
\hline Filler & 10.32 & 11.00 & $\begin{array}{c}10 \ldots .14 \% \\
(\mathrm{~A})\end{array}$ & $\begin{array}{c}10 \ldots .14 \% \\
(\mathrm{~A})\end{array}$ & \\
\hline $\begin{array}{c}\text { Bitumen + } \\
\text { additiv }\end{array}$ & 5.90 & 6.289 & $\begin{array}{c}\min 5.9 \% \\
(\mathrm{M})\end{array}$ & $\begin{array}{c}\min 5.9 \% \\
(\mathrm{M})\end{array}$ & $\mathrm{TL}_{\min 5.8}$ \\
\hline Fiber & 0.30 & 0.32 & - & 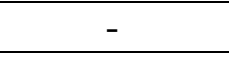 & - \\
\hline Total & 100 & 106.61 & - & - & - \\
\hline
\end{tabular}

The results of the physical and mechanical tests are presented in the following table:

Table 5. Physico-mechanical characteristics of the laboratory prepared preparation for the MAS 16

\begin{tabular}{|l|l|l|l|l|l|l|}
\hline $\begin{array}{l}\text { Nr. } \\
\text { Crt }\end{array}$ & Characteristic & UM & Recipe & $\begin{array}{l}\text { Technical } \\
\text { condition } \\
\text { from } \\
\text { AND } \\
605 / 2013\end{array}$ & $\begin{array}{l}\text { Technical } \\
\text { condition } \\
\text { from } \\
\text { AND } \\
605 / 2014\end{array}$ & $\begin{array}{l}\text { Category } \\
\text { from SR EN } \\
13108-5 \text { SR } \\
\text { EN 13108-1 }\end{array}$ \\
\hline $\mathbf{1}$ & Apparent density & $\mathrm{Kg} / \mathrm{m}^{3}$ & 2309 & - & - & - \\
\hline $\mathbf{2}$ & $\begin{array}{l}\text { Maximum density } \\
\text { of asphalt mix, } \\
\text { Gmm }\end{array}$ & $\mathrm{Kg} / \mathrm{m}^{3}$ & 2348 & - & - & - \\
\hline $\mathbf{3}$ & Air volume, Vm & $\%$ & 3.9 & - & $3-4$ & $3-4$ \\
\hline $\mathbf{4}$ & $\begin{array}{l}\text { Volume of voids } \\
\text { filled with bitumen, } \\
\text { VFB }\end{array}$ & $\%$ & 77.2 & $77-83$ & $77-83$ & $71-86$ \\
\hline $\mathbf{5}$ & $\begin{array}{l}\text { Percentage of voids } \\
\text { in aggregates,VMA }\end{array}$ & $\%$ & 17.1 & - & - & Min 14 \\
\hline $\mathbf{6}$ & Water absorption & $\%$ & 1.52 & - & - & - \\
\hline $\mathbf{7}$ & $\begin{array}{l}\text { Stability (S) at 60 } \\
{ }^{\circ} \mathbf{C}\end{array}$ & $\mathrm{KN}$ & 9.9 & - & - & $7.5-15$ \\
\hline
\end{tabular}




\begin{tabular}{|l|l|l|l|l|l|l|}
\hline 8 & Flow (I) at 60 & \\
\end{tabular}

\section{Variation of dynamic creep phenomenon of MAS 16}

Creep test was performed according to Romanian norms in vigor (SR 12697-25 / 2008) for determining the physical and mechanical properties of asphalt mixtures.

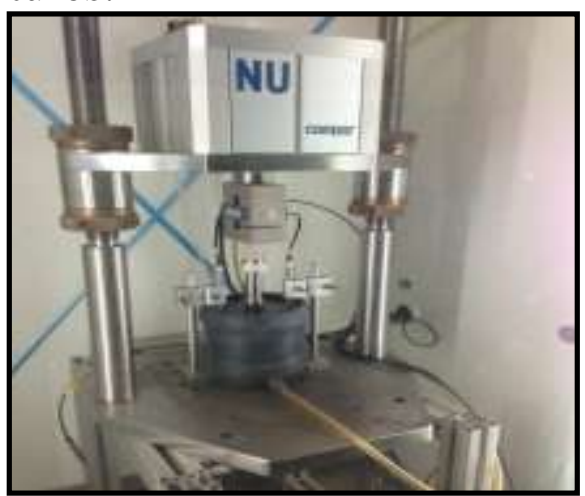

Figure 13. Test equipment for dynamic creep

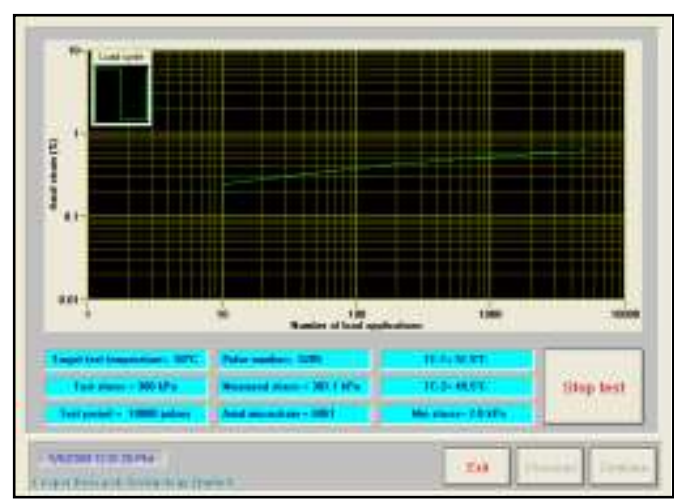

Figure 14. Recording the axial deformation according to the number of pulses

The determination of the variation of the dynamic fluctuation phenomenon was made taking into account the following conditions:

冈 Test temperature: $50^{\circ} \mathrm{C}, 60^{\circ} \mathrm{C}, 70^{\circ} \mathrm{C}$;

$\otimes$ Vertical stress applied: 250kpa;

Number of pulses: 10000 ;

冈inding pressure: 0.8 bar

冈 Period: $120 \mathrm{sec}$;

冈 Frecquency of applied stress: $1 \mathrm{sec}$. load, $1 \mathrm{sec}$. unloading.

Determination of resistance to permanent deformations (dynamic creep) was made taking into account the conditions listed above, and the obtained responses for the different temperatures studied are represented in Figure 15. 
ROMANIAN JOURNAL

\section{OF TRANSPORT INFRASTRUCTURE}

Mihai DICU, Isam MIRZA, Flavius - Florin PAVĂL

Influence of high temperatures on technical state of streets and roads structures with asphalt surfacing

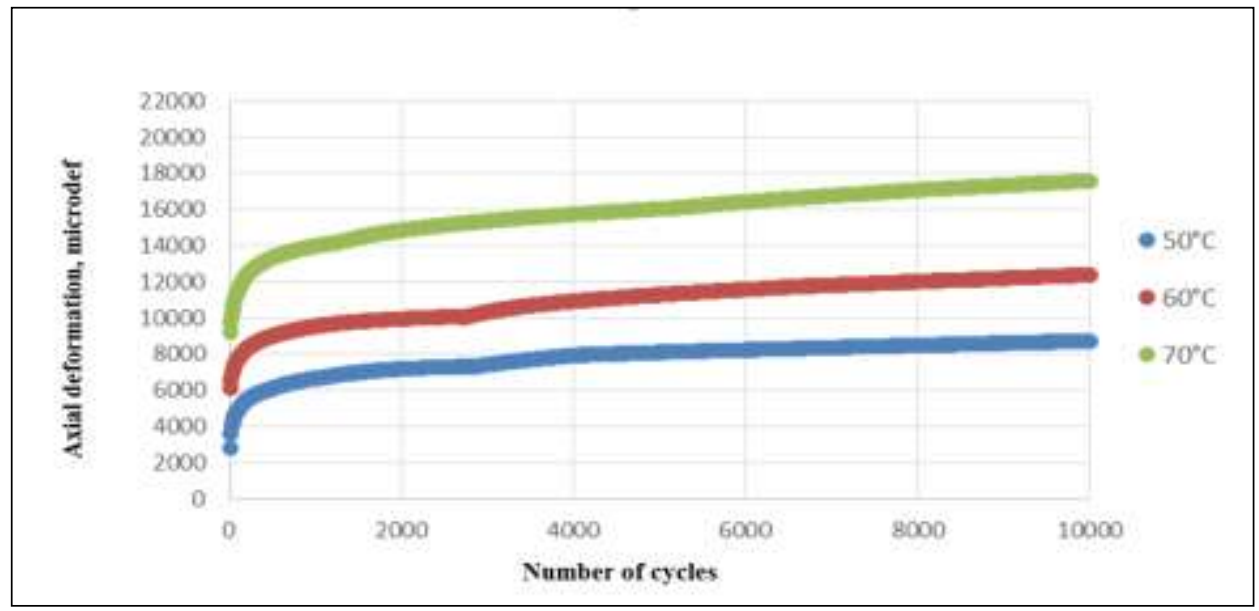

Figure 15. Creep curve for MAS 16 at different temperatures

The creep modulus for asphalt mix MAS 16 determined at the test temperatures is shown in Figure 16.

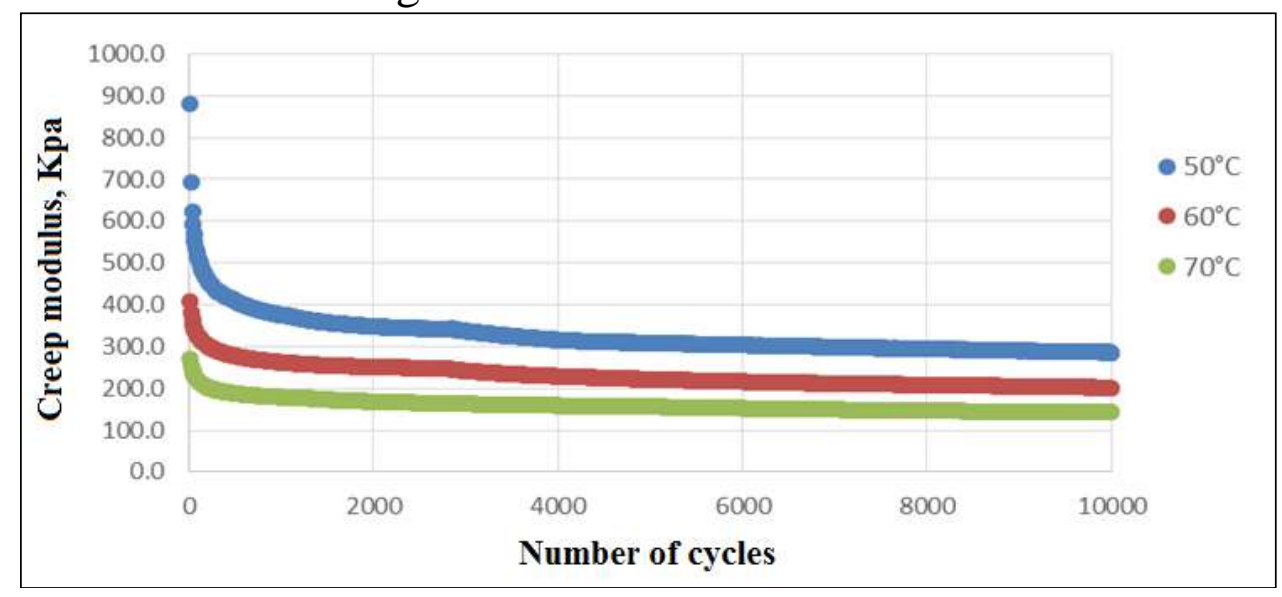

Figure 16. Creep modulus for MAS 16 at different temperatures

Creep results using a first method of calculating and calculating creep modules are shown in Table 6.

Tabel 6. Creep results, (Method I) and creep modulus values

\begin{tabular}{|c|c|c|c|c|}
\hline Mixture & $\begin{array}{c}\text { Parameters of } \\
\text { equation on } \\
\text { (quasi) linear stage } \\
\text { II Method I } \\
\left(\varepsilon_{n}=A_{1}+B_{1} n\right)\end{array}$ & $\begin{array}{c}\text { Creep rate } \\
f_{c}=B_{1}\end{array}$ & $\begin{array}{c}\text { Creep modulus } E_{n}=\sigma / \varepsilon_{n}, \\
\mathrm{kpa}\end{array}$ \\
\hline${ }^{\circ} \mathrm{C}$ & & & \\
\hline
\end{tabular}


ROMANIAN JOURNAL

OF TRANSPORT INFRASTRUCTURE

Mihai DICU, Isam MIRZA, Flavius - Florin PAVĂL

Influence of high temperatures on technical state of streets and roads structures with asphalt surfacing

\begin{tabular}{|c|c|c|c|c|c|c|c|}
\hline & & $\mathrm{A} 1$ & $\mathrm{~B} 1$ & & initial & 1000 & 10000 \\
\hline \multirow{3}{*}{ MAS16 } & $50{ }^{\circ} \mathrm{C}$ & 7482 & 0.1263 & 0.1263 & 879 & 375 & 286 \\
\cline { 2 - 8 } & $60{ }^{\circ} \mathrm{C}$ & 10303 & 0.2116 & 0.2116 & 408 & 262 & 202 \\
\cline { 2 - 8 } & $70^{\circ} \mathrm{C}$ & 14561 & 0.309 & 0.309 & 272 & 179 & 142 \\
\hline
\end{tabular}

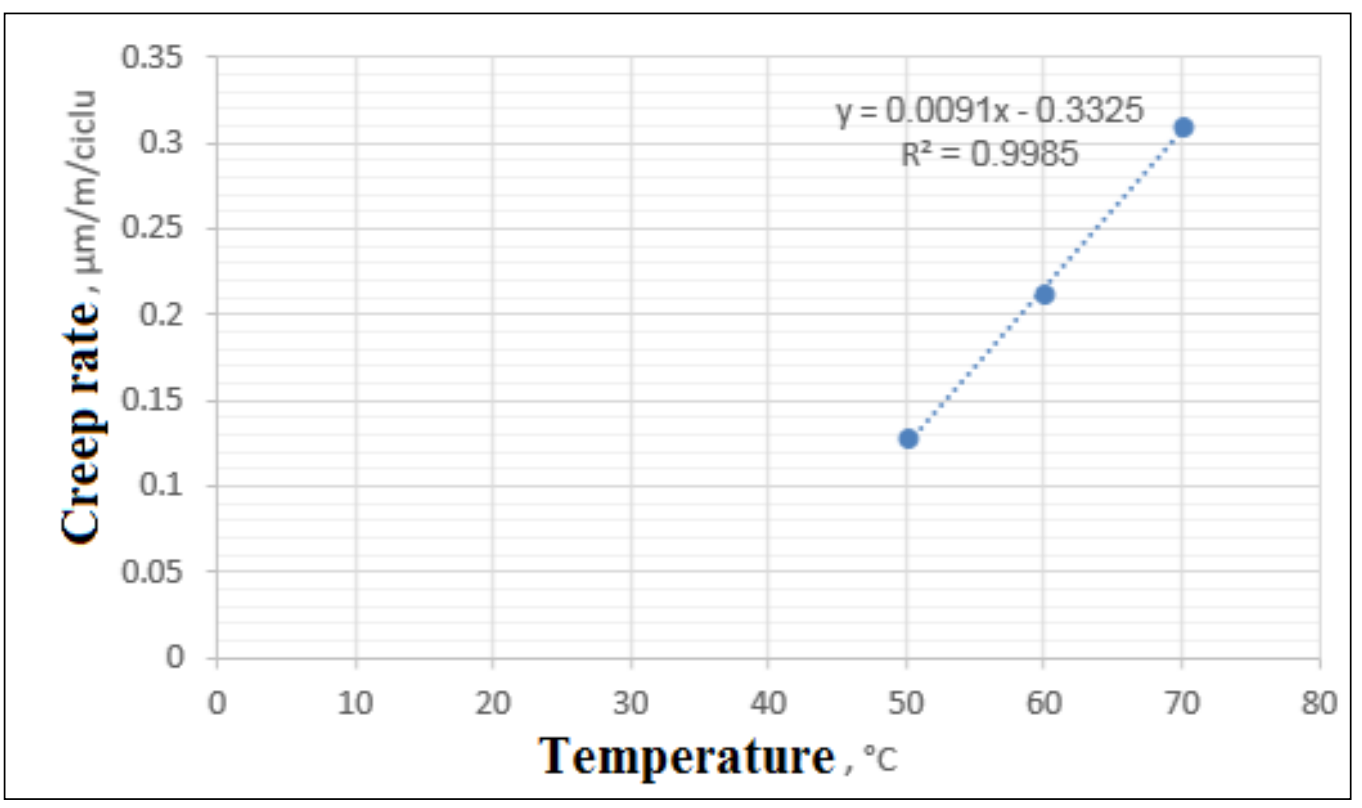

Figure 17.Variation of creep rate of mixture MAS 16 at different temperatures

Creep rate of MAS 16 correlates with temperature through an equation with the form:

$$
\mathrm{y}=0.0091 \mathrm{x}+0.3325 \quad \mathrm{R} 2=0.9985
$$

Where: $y$ is creep rate; $\mathrm{x}$ is temperature.

Creep results using a second method of calculation are shown in Table 7.

Tabel 7. Creep results, method II

\begin{tabular}{|c|c|c|c|c|c|}
\hline \multirow[t]{2}{*}{ Mixture } & \multirow[t]{2}{*}{$\stackrel{\text { Temperature }}{{ }^{\circ} \mathrm{C}}$} & \multicolumn{2}{|c|}{$\begin{array}{c}\text { Parameters of } \\
\text { Equation on (quasi) } \\
\text { Linear Stage II } \\
\text { Method II } \\
\left(\log \varepsilon_{n}=\log A+\log B\right. \\
n)\end{array}$} & \multirow[t]{2}{*}{$\begin{array}{l}\text { Calculated } \\
\text { Permanent } \\
\text { Deformation } \\
\varepsilon_{1000}: \\
\varepsilon_{1000}=\mathrm{A} \\
1000^{B}\end{array}$} & \multirow[t]{2}{*}{$\begin{array}{l}\text { Calculated } \\
\text { Permanent } \\
\text { Deformation } \\
\varepsilon_{10000}: \\
\quad \varepsilon_{10000}=\mathrm{A} \\
\quad 10000^{B}\end{array}$} \\
\hline & & A & B & & \\
\hline & $50{ }^{\circ} \mathrm{C}$ & 3186 & 0.1092 & 6775 & 8712 \\
\hline
\end{tabular}




\begin{tabular}{|c|c|c|c|c|c|}
\hline \multirow{2}{*}{ MAS16 } & $60{ }^{\circ} \mathrm{C}$ & 3707 & 0.1309 & 9156 & 12377 \\
\cline { 2 - 6 } & $70^{\circ} \mathrm{C}$ & 5804 & 0.1347 & 12891 & 17579 \\
\hline
\end{tabular}

\section{CONCLUSIONS}

Conclusions from studies of the dynamic creep test:

There is a large number of both construction and operating differences between urban and extra urban road infrastructures.

This article mentions the differences between street and road users, but the most important thing was the presentation of totally different environmental conditions that, in conjunction with traffic demands, lead to degradation.

In the case of streets due to the buildings, the large number of cars and the engines driven due to low speeds, agglomerations and congestion and lack of vegetation, the temperatures recorded in the air are much higher than those recorded for the extra-urban environment where we find the roads.

Compared to the air temperatures recorded at a height of 2 meters, it should be taken into account that the temperatures recorded at the road surface are much higher even double.

Studies conducted to determine the resistance to permanent deformations by testing the dynamic creep of the MAS 16 asphalt mix were evaluated at several temperatures $\left(50^{\circ} \mathrm{C}, 60^{\circ} \mathrm{C}\right.$ and $\left.70^{\circ} \mathrm{C}\right)$.

If we refer to the resistance to permanent deformations in this research study on the studied asphalt mix, we consider the following: interpretation of the creep curve results, creep speed, creep mode, permanent deformation calculated after 1000 and 10000 pulses.

If the temperature rises from $50^{\circ} \mathrm{C}$ to $60^{\circ} \mathrm{C}$, the results obtained for the permanent deformation test after 10000 pulses are $41 \%$ higher, from $60^{\circ} \mathrm{C}$ to $70^{\circ} \mathrm{C}$ the dynamic fluctuation is $42 \%$ higher.

Creep speed increases as temperature increases; It can be noticed that at a temperature increase from $60^{\circ} \mathrm{C}$ to $70^{\circ} \mathrm{C}$ the creep speed increases by $46 \%$. The value of the creeper module decreases with the number of load applications and temperature increases.

\section{BIBLIOGRAPHY}




\section{ROMANIAN JOURNAL \\ OF TRANSPORT INFRASTRUCTURE}

Mihai DICU, Isam MIRZA, Flavius - Florin PAVĂL

Influence of high temperatures on technical state of streets and roads structures with asphalt surfacing

[1]. A. BURLACU, C. RĂC̆̌NEL: „, Permanent deformations of asphalt mixtures from pavement wearing courses", 2nd International Conference on Road and Rail Infrastructure, CETRA 2012, Croatia

[2]. D. Metcalf, T. C., 1963. Design curves of flexible pavements based on layered system theory, Highway Research Record No. 71.

[3]. E. DIACONU, M. DICU, C. RĂCĂNEL: “Căi de comunicaţii rutiere principii de proiectare" - 2006, CONPRESS, Bucureşti;.

[4]. F.F. PAVĂL: Raport de cercetare nr. 1 - "Cauzele apariţiei degradărilor la străzi clasificare şi măsuri de remediere preconizate" - 2015, București;

[5]. I. MIRZA: Raport de cercetare $n r .3$ - "Modelare experimentala pentru analiza prin incercari dinamice a performantelor mixturilor asfaltice solicitate la temperaturi ridicate”-2016, Bucuresti.

[6]. SR EN 12697-25, 2008. Mixturi asfaltice. Metode de incercare pentru mixturi asfaltice preparate la cald. Incercarea la compresiune ciclica. 